\title{
Profil Penggunaan Obat Antianemia, Antihipertensi, dan Antidiabetik pada Pasien Penyakit Ginjal Kronik di Salah Satu Rumah Sakit Wilayah Surabaya Selatan
}

\author{
Drug Utilization Profile of Antianemic, Antihypertensive, and Antidiabetic in \\ Patients with Chronic Kidney Disease in a Hospital at the South Surabaya Region
}

\author{
Ninik Mas Ulfa*, lin Ernawati, Purwanti, Riki Kurniawanto, Ari Indrawati \\ Akademi Farmasi Surabaya, Jl. Ketintang Madya No. 81, \\ Surabaya 60231, Indonesia \\ *Corresponding author email: ninik.mu@akfarsurabaya.ac.id
}

Received 16-10-2019 Accepted 30-11-2019 Available online 30-12-2019

\begin{abstract}
ABSTRAK
Penyakit ginjal kronis (PGK) merupakan gangguan fungsi renal yang progresif dimana kemampuan tubuh gagal untuk mempertahankan metabolisme dan keseimbangan cairan elektrolit dan menyebabkan uremia. Tujuan penelitian ini untuk mengetahui profil penggunaan obat antianemia, antihipertensi, dan antidiabetik pada pasien PGK dengan hemodialisa. Penelitian ini dilakukan di Rumah Sakit Wilayah Surabaya Selatan. Penelitian ini bersifat deskriptif observasional menggunakan data secara retrospektif, pada bulan Januari-Maret 2018. Berdasarkan hasil penelitian diperoleh pada pemakaian obat antianemia dengan menggunakan EPO alfa 2000 IU dan 3000 IU, keduanya dapat meningkatkan kadar $\mathrm{Hb}$. Variasi dosis EPO alfa yang digunakan yaitu dosis $2000 \mathrm{IU}$ sebanyak $60 \%$ pasien dan 3000 IU sebanyak 40\% pasien. Untuk obat antihipertensi pemakaian terbanyak kombinasi irbesartan $300 \mathrm{mg}$ dan amlodipine $10 \mathrm{mg}$ dengan frekuensi pemberian 1 kali sehari 1 tablet. Antidiabetik yang digunakan pada pasien PGK adalah kombinasi insulin basal dan prandial sebanyak $80 \%$ daripada terapi OAD atau insulin tunggal. Pada golongan sulfonilurea digunakan gliquidone dosis $30 \mathrm{mg}$ dengan frekuensi satu kali sehari (20\%). Golongan insulin paling banyak diberikan adalah kombinasi insulin analog kerja panjang dan insulin aspart analog kerja cepat (34\%).
\end{abstract}

Kata kunci: antianemia, antidiabetik, antihipertensi, penyakit ginjal kronik, profil peresepan.

\begin{abstract}
Chronic kidney disease (CKD) is a progressive disruption of renal function in which the body's ability fails to maintain metabolism and electrolyte fluid balance. The purpose of this study was to determine the drug utilization profile of antianemic, antihypertensive,
\end{abstract}


and antidiabetic in CKD patients with hemodialysis. This research was conducted at a hospital at the South Surabaya. This research is a descriptive observational study using retrospective data from January to March 2018. The results of the study showed the antianemic drugs used were EPO alpha $2000 \mathrm{IU}$ and $3000 \mathrm{IU}$, which were able to increase hemoglobin levels. The EPO alpha at doses of $2000 \mathrm{IU}$ and $3000 \mathrm{IU}$ were used by 60 and $40 \%$ patients, respectively. A combination of $300 \mathrm{mg}$ irbesartan and $10 \mathrm{mg}$ amlodipine once daily was the most commonly used antihypertensive drugs. The most used antidiabetic drugs were a combination of basal insulin and oral antidiabetic agent (80\%), much more than that of single insulin or oral antidiabetic therapy. The most commonly given oral antidiabetic was gliquidone $30 \mathrm{mg}$ once a day (20\%), while the most prescribed insulin was the combination of long-and fast working analog aspart (34\%).

Key words: antianemic, antidiabetic, antihypertensive, chronic kidney disease, medication profile.

\section{Pendahuluan}

Penyakit Ginjal Kronis (PGK, Chronic Kidney Disease/CKD) atau penyakit renal tahap akhir merupakan gangguan fungsi renal yang progresif dan irreversible dimana kemampuan tubuh gagal untuk mempertahankan metabolisme dan keseimbangan cairan dan elektrolit sehingga menyebabkan uremia (retensi urea dan sampah nitrogen lain dalam darah). Penyakit ini merupakan penyakit yang tidak dapat pulih, dimana ditandai dengan penurunan fungsi ginjal secara progresif dan mengarah pada penyakit ginjal tahap akhir atau end stage renal disease (ESRD). Faktor penyebab penyakit ini antara lain gangguan pada sistim kardiovaskular termasuk hipertensi, penyakit gangguan tulang, dyslipidemia (NKF, 2002).

PGK dalam perkembangannya dapat menimbulkan berbagai komplikasi seperti anemia, hipertensi, asidosis metabolik, hiperparatiroid, metabolic bone disease, serta gangguan cairan dan elektrolit. Pada penelitian ini ingin diketahui profil pengobatan pasien PGK yang meliputi anemia, hipertensi, dan diabetes melitus. Anemia merupakan salah satu komplikasi pada PGK dan anemia disebut sebagai konsentrasi hemoglobin $(\mathrm{Hb})$ yang kurang dari 13,5 g/dL pada laki-laki dewasa dan kurang dari $12 \mathrm{~g} / \mathrm{dL}$ pada wanita dewasa (Lankhorst dan Wish, 2010). Nefropati diabetik adalah gangguan fungsi ginjal akibat kebocoran selaput penyaring darah. Sebagaimana diketahui, ginjal terdiri dari jutaan unit penyaring (glomerolus) (Suprapti dan Nilamsari, 2013). Pasien PGK di rumah sakit tempat penelitian ini mengalami peningkatan. Sehingga peneliti tertarik untuk mengetahui profil penggunaan obat antianemia, antihipertensi, dan antidiabetik yang sering digunakan pada pasien PGK.

\section{Metode Penelitian \\ Penelitian ini merupakan penelitian observasional menggunakan}


metode analisis deskriptif dengan pengamatan secara retrospektif pada data pasien PGK periode Januari sampai Maret 2018. Instrumen yang digunakan adalah Rekam Medik Kesehatan (RMK) pasien.

Sampel penelitian yang digunakan adalah semua pasien di Rumah Sakit Bhayangkara H.S. Samsoeri Mertojoso Surabaya, yang didiagnosis mengalami penyakit ginjal kronik disertai anemia, hipertensi, dan diabetes dan menjalani hemodialisis. Kriteria data dibagi menjadi 2, yaitu:

1. Kriteria data inklusi

a. Data RMK pada pasien dengan diagnosa PGK yang menjalani hemodialisis dan mendapatkan terapi antianemia, antihipertensi, antidiabetes.

b. Dokumen RMK yang lengkap dan jelas terbaca.

2. Kriteria data eksklusi

a. Dokumen RMK dari pasien yang telah sesuai dengan data inklusi namun pasien tersebut telah meninggal dunia, sehingga tidak dapat digunakan sebagai sampel.

b. Dokumen RMK dari pasien yang telah sesuai dengan data inklusi namun pasien tersebut telah dirujuk ke rumah sakit yang lain, sehingga tidak dapat digunakan sebagai sampel.

Berdasarkan kriteria inklusi diperoleh jumlah pasien PGK yang mendapat terapi antianemia berupa eritopoeitin sebanyak 10 pasien. Sedangkan pasien PGK yang mendapatkan obat antihipertensi sebanyak 19 Pasien, dan pasien PGK yang mendapatkan obat antidiabetes sebanyak 15 orang. Jadi total pasien dalam penelitian ini yang memenuhi kriteria inklusi adalah 44 pasien.

\section{Hasil dan Pembahasan}

Karakteristik Jenis kelamain dan Usia Pasien PGK yang menjalani Hemodialisa (HD) dan mendapat Terapi Pengobatan Eritropoetin, Antihipertensi, Antidiabetik

Berdasarkan hasil pengamatan penelitian tentang data demografi pasien PGK diperoleh hasil bahwa pasien PGK yang mendapat terapi obat antianemia sebanyak 10 pasien, dengan jumlah pasien laki-laki lebih banyak $70 \%$ dibandingkan pasien perempuan $30 \%$, sedangkan untuk kategori usia didapatkan hasil bahwa pasien PGK yang paling banyak mendapat terapi obat antianemia adalah antara usia 56-65 tahun. Sedangkan pada pasien PGK yang mendapat obat antihipertensi sebanyak 19 pasien, dengan jenis kelamin terbanyak adalah laki-laki $74 \%$ dan perempuan $26 \%$, untuk usia terbanyak pada rentang 36-45 tahun. Pada penelitian ini juga mengamati pasien PGK yang mendapat obat antidiabetik, dengan jumlah pasien laki-laki lebih banyak 53\% dibandingkan pasien perempuan $47 \%$, rentang usia terbanyak pada usia 56-65 tahun. Berdasarkan data hasil penelitian tersebut menyatakan bahwa prevalensi terbanyak diderita pada usia dewasa produktif hingga lanjut usia, hal ini menunjukkan bahwa bertambahnya usia 
menyebabkan menurunnya fungsi organorgan tubuh, salah satunya adalah penurunan fungsi organ ginjal yang dapat diiringi dengan penurunan fungsi organ tubuh lainnya yaitu jantung, pankreas, otak, dan sebagainya. Seiring dengan bertambahnya umur maka secara fisiologis terjadi penurunan fungsi organ ginjal namun ada banyak faktor yang menyebabkan menurunnya fungsi organ ginjal secara progresif (Pranandari dan Supadmi, 2015). Pola hidup yang tidak sehat sehingga menyebabkan kerusakan sel-sel organ tubuh yang sangat vital yaitu jantung dan pembuluh darah maupun ginjal, akibatnya dapat menurunkan fungsi ginjal dan jantung.
Selain faktor tersebut, adanya penyakit diabetes melitus yang tidak teregulasi dengan baik dari segi terapi pengobatan dapat menyebabkan kerusakan mikrovaskular dan makrovaskular. Kerusakan mikrovaskular di antaranya adalah nefropati, neuropati, retinopati. Sedangkan kerusakan makrovaskular yaitu gangguan pada sistem kardiovaskular yang dapat mengakibatkan hipertensi hingga stroke (Perkeni, 2015). Tabel 1 menunjukkan hasil penelitian berdasarkan karakteristik jenis kelamin dan usia pasien PGK yang menjalani hemodialisa dan mendapat terapi obat antianemia, atau obat antihipertensi, atau obat antidiabetik.

Tabel 1. Karakteristik jenis kelamin dan usia pasien gagal ginjal kronik yang mendapat terapi antianemia, antihipertensi, dan antidiabetik

\begin{tabular}{ccccccc}
\hline Terapi & $\begin{array}{c}\text { Jenis } \\
\text { Kelamin }\end{array}$ & Jumlah & $\begin{array}{c}\text { Persentase } \\
\text { (\%) }\end{array}$ & $\begin{array}{c}\text { Usia } \\
\text { (Tahun) }\end{array}$ & Jumlah & $\begin{array}{c}\text { Persentase } \\
\text { (\%) }\end{array}$ \\
\hline Antianemia & Laki-Laki & 7 & 70 & $36-45$ & 1 & 10 \\
& Perempuan & 3 & 30 & $46-55$ & 1 & 10 \\
& Total & 10 & 100 & $56-65$ & 6 & 60 \\
& & & & $>65$ & 4 & 20 \\
Antihipertensi & Laki-laki & 14 & 74 & $26-35$ & 4 & 100 \\
& Perempuan & 5 & 26 & $36-45$ & 6 & 32 \\
& Total & 19 & 100 & $46-55$ & 4 & 21 \\
& & & & $56-65$ & 5 & 26 \\
& & & & $>65$ & 0 & 0 \\
Andiabetik & Laki-laki & 8 & 53 & $26-35$ & 0 & 0 \\
& Perempuan & 7 & 47 & $36-45$ & 1 & 7 \\
& Total & 15 & 100 & $46-55$ & 5 & 33 \\
& & & & $56-65$ & 9 & 60 \\
& & & & $>65$ & 0 & 0 \\
& & & & Total & 15 & 100 \\
\hline Total Pasien & & & & & & \\
\hline
\end{tabular}


Profil Penggunaan Terapi Obat pemberian injeksi intravena obat dengan Antianemia pada Pasien Gagal Ginjal nama generik epo alfa $(\alpha)$ dosis $2000 \mathrm{UI}$ Kronik dengan Hemodialisa

Berdasarkan hasil penelitian sebanyak $60 \%$ dan injeksi epo alfa dosis diperoleh bahwa terapi obat antianemia pada PGK yang menjalani HD adalah 3000 UI sebanyak 40\%. Hasil tersebut dapat dilihat pada Tabel 2.

Tabel 2. Profil penggunaan terapi antianemia pada pasien gagal ginjal kronik yang menjalani hemodialisa berdasarkan nama generik dan dosis

\begin{tabular}{lccc}
\hline Nama Generik Obat & Dosis & Jumlah Pasien & Persentase (\%) \\
\hline Epo alfa & $2000 \mathrm{UI}$ & 6 & 60 \\
Epo alfa & $3000 \mathrm{UI}$ & 4 & 40 \\
\hline Total & & 10 & 100 \\
\hline
\end{tabular}

Pada parameter pengukuran interval pemberian injeksi epo dalam penelitian ini diberikan $2 \times$ dalam seminggu baik epo alfa $2000 \mathrm{UI}$ maupun epo alfa 3000 UI. Sedangkan untuk banyaknya pemberian yaitu pada epo alfa 2000 UI diberikan sebanyak 5 syringe dan epo alfa $(\alpha)$ sebanyak 8 syringe. Untuk 1 kali pemberian sebanyak 1 syringe, sehingga pada pemberian epo alfa $2000 \mathrm{Ul}$ akan habis dalam waktu 2 minggu, dan $3000 \mathrm{UI}$ akan habis dalam waktu 3 minggu. Pada pemberian epo alfa ini baik $2000 \mathrm{UI}$ maupun $3000 \mathrm{UI}$ dapat meningkatkan nilai hemoglobin pasien tersebut. Peningkatan HB setelah pemberian epo alfa baik $2000 \mathrm{UI}$ maupun $3000 \mathrm{UI}$ ini dikarenakan mekanisme kerjanya yaitu menstimulasi siklus eritropoiesis sehingga terjadi peningkatan jumlah sel progenitor yang terikat untuk eritropoiesis, akibatnya reseptor erythropoietin (EPO) terangsang untuk berproliferasi, berdiferensiasi dengan tujuan untuk menghasilkan hemoglobin (Hoffbrand et al., 2012). Hasil tersebut dapat dilihat pada Tabel 3.

Profil Penggunaan Terapi Obat Antihipertensi pada Pasien Gagal Ginjal yang Menjalani Hemodialisa

Dari hasil penelitian diperoleh terapi obat antihipertensi pada pasien gagal ginjal kronik yang menjalani hemodialisa adalah terapi kombinasi obat antihipertensi yaitu golongan Angiotensin Receptor Blocker (ARB) dengan golongan Calcium Channel Blocker (CCB), sejumlah 19 pasien (100\%) yang mendapat terapi kombinasi golongan obat tersebut. Golongan ARB yang paling banyak diresepkan dengan nama generik obat pada terapi kombinasi tersebut adalah irbersartan (100\%) dan golongan CCB yang paling banyak digunakan dengan nama generik obat adalah amlodipin (95\%) dan nifedipin oros (5\%). Pada penelitian ini 
pengunaan obat antihipertensi golongan ARB dengan nama generik obat irbersartan lebih banyak digunakan, hal ini dikarenakan mempunyai sifat rhenoprotektif yaitu melindungi fungsi ginjal. Mekanisme kerja dari golongan ARB adalah menghambat reseptor angiotensin 1 (AT-1) sehingga terjadi efek vasodilatasi pada pembuluh darah di ginjal, sehingga dapat menghambat sistem Renin Angiotensin Aldosterone (RAA). Keunggulan lain yaitu irbersartan diberikan pada PGK dengan HD jika pemberian golongan Angitensin Converting Enzyme Inhibitor (ACEI) tidak dapat ditolerir lagi dari faktor eliminasi dan ekskresi obat oleh ginjal, sehingga dipilih penggunaan obat golongan ARB yaitu irbersartan dengan keunggulan farmakokinetiknya yaitu diekskresi oleh ginjal 33\% dan ekskresi oleh empedu 67\% (Lewis et al., 2001). Waktu paruh irbersartan pada pasien gagal ginjal kronik adalah 11-15 jam sama dengan waktu paruh normalnya. Sedangkan pada kondisi pasien dilakukan hemodialisa, irbersartan ikut terbuang saat proses hemodialisis (0\%) (Ahmad et al., 2016).

Tabel 3. Profil jumlah pemberian epo alfa $(\alpha)$ dan peningkatan kadar hemoglobin pada pasien gagal ginjal kronik yang menjalani hemodialisa

\begin{tabular}{|c|c|c|c|c|}
\hline $\begin{array}{l}\text { No. Urut } \\
\text { Pasien }\end{array}$ & $\begin{array}{l}\text { Terapi Obat } \\
\text { Antianemia }\end{array}$ & $\begin{array}{l}\text { Kadar HB- } \\
\text { pre (g/dl) }\end{array}$ & $\begin{array}{c}\text { Jumlah Pemberian Epo } \\
\text { Alfa }(\alpha) \text { (Syringe) }\end{array}$ & $\begin{array}{l}\text { Kadar HB- } \\
\text { post }(\mathrm{g} / \mathrm{dl})\end{array}$ \\
\hline 1 & EPO Alfa $(\alpha) 2000$ UI & 7,3 & 5 & 8,5 \\
\hline 2 & EPO Alfa $(\alpha) 2000 \mathrm{UI}$ & 7,2 & 5 & 8,4 \\
\hline 3 & EPO Alfa $(\alpha) 2000 \mathrm{UI}$ & 7,3 & 5 & 8,3 \\
\hline 4 & EPO Alfa $(\alpha) 2000 \mathrm{UI}$ & 7,2 & 5 & 9,0 \\
\hline 5 & EPO Alfa $(\alpha) 2000 \mathrm{UI}$ & 7,3 & 5 & 8,5 \\
\hline 6 & EPO Alfa $(\alpha) 2000 \mathrm{UI}$ & 6,9 & 5 & 7,8 \\
\hline 7 & EPO Alfa $(\alpha) 3000 \mathrm{UI}$ & 7,4 & 8 & 7,8 \\
\hline 8 & EPO Alfa $(\alpha) 3000 \mathrm{UI}$ & 9,1 & 8 & 10,7 \\
\hline 9 & EPO Alfa $(\alpha) 3000$ UI & 10,5 & 8 & 12,0 \\
\hline 10 & EPO Alfa $(\alpha) 3000$ UI & 10,1 & 8 & 11,4 \\
\hline
\end{tabular}

Terapi kombinasi antihipertensi yang paling banyak diresepkan adalah kombinasi golongan 1 ARB +1 CCB (95\%) dengan nama generik obat irbersartan $300 \mathrm{mg}$ atau $150 \mathrm{mg}$ dan amlodipin 10 $\mathrm{mg}$ atau $5 \mathrm{mg}$. Sedangkan kombinasi golongan 1 ARB dan 2 CCB (5\%) dengan nama generik obat irbersartan $150 \mathrm{mg}+$ amlodipin $10 \mathrm{mg}+$ nifedipin oros $30 \mathrm{mg}$.
Untuk dosis irbersartan yang paling banyak diresepkan adalah dosis $300 \mathrm{mg}$ (63\%) dan $150 \mathrm{mg}$ (37\%). Untuk dosis amlodipin yang paling banyak diresepkan adalah $10 \mathrm{mg}$ (95\%) dan $5 \mathrm{mg}$ (5\%), sedangkan nifedipin oros dosis 30 mg (5\%). Pemilihan amlodipin dalam terapi kombinasi ini, dikarenakan amlodipin mempunyai kelebihan 
dibandingkan golongan CCB lainnya. Amlodipin merupakan golongan CCB dihidropiridin dengan mekanisme kerja menghambat masuknya ion calsium intra sel, sehingga mengakibatkan waktu depolarisasi otot polos jantung lebih panjang. Keunggulan amlodipin dibandingkan CCB lainnya pada pasien gagal ginjal kronik adalah waktu paruh amlodipin ditolerir dengan baik pada pasien gangguan fungsi ginjal sehingga tidak mengalami perubahan seperti waktu paruh normal, jadi tidak memerlukan penyesuaian dosis (Paranoan et al., 2019). Sedangkan pengamatan frekuensi pemberian pada penelitian ini adalah irbersartan dosis $150 \mathrm{mg}$ maupun $300 \mathrm{mg}$ adalah 1 kali sehari 1 tablet, untuk amlodipin dosis 5 $\mathrm{mg}$ maupun $10 \mathrm{mg}$ pada penelitian ini adalah 1 kali sehari 1 tablet. Dari segi farmakokinetik waktu paruh baik amlodipin maupun irbersartan yang diberikan pada pasien gagal ginjal mempunyai waktu paruh yang tidak berubah dengan waktu paruh normal. Waktu paruh amlodipin 50 jam pada dosis $5 \mathrm{mg}$ maupun $10 \mathrm{mg}$, sedangkan pada saat dilakukan hemodialisis, amlodipin dapat terdialisis sempurna dari tubuh tanpa ada sisa (0\%) (Ahmad et al., 2016). Pada dosis dan frekuensi pemberian dari irbersartan maupun amlodipin ini sudah sesuai untuk pasien PGK berdasarkan The Renal Drug Handbook (Burns et al., 2009). Hasil tersebut dapat dilihat pada Tabel 4, 5, dan 6.

Tabel 4. Profil golongan obat dan nama generik obat antihipertensi pada pasien gagal ginjal kronik yang menjalani hemodialisa

\begin{tabular}{lccc}
\hline \multicolumn{1}{c}{ Nama Golongan Obat } & Nama Generik Obat & Jumlah Pasien & Persentase (\%) \\
\hline Angiotensin Receptor Blocker & Irbersartan & 19 & 100 \\
Calcium Channel Blocker & Amlodipin & 18 & 95 \\
& Nifedipin & 1 & 5 \\
\hline
\end{tabular}

Profil Penggunaan Terapi Obat Antidiabetik pada Pasien Gagal Ginjal yang Menjalani Hemodialisa

Hasil penelitian yang diperoleh adalah untuk terapi obat-obat antidiabetik baik oral antidiabetes (OAD) maupun injeksi insulin pada 15 pasien PGK yang menjalani HD adalah terbanyak mendapatkan kombinasi injeksi insulin sebanyak $67 \%$, pasien yang mendapatkan OAD tunggal sebanyak $20 \%$, sedangkan kombinasi insulin +
OAD sebanyak $13 \%$. Untuk golongan OAD tunggal pemakaian terbanyak adalah golongan sulfonilurea sebanyak $20 \%$ dengan nama generik obat glikuidon $30 \mathrm{mg}$ dan frekuensi pemberian 1 kali sehari 1 tablet. Sedangkan untuk pemakaian kombinasi injeksi insulin, yang terbanyak adalah kombinasi golongan insulin kerja panjang dengan insulin aspart analog kerja cepat sebanyak 34\%. Untuk penggunaan insulin tunggal adalah insulin kerja cepat 
sebanyak $6,7 \%$ dan insulin analog kerja panjang sebanyak 6,7\%. Sedangkan untuk pemakaian OAD kombinasi 1 insulin adalah glikuidon $30 \mathrm{mg}+$ insulin analog campuran sebanyak $6,6 \%$ dan pemakaian OAD kombinasi 2 insulin adalah glikuidon $30 \mathrm{mg}+$ insulin analog kerja panjang + insulin analog kerja cepat sebanyak $6,6 \%$. Pada pemberian insulin diperoleh hasil bervariasi pada pengamatan dosis dan frekuensi pemberian. Hasil tersebut dapat dilihat pada Tabel 7 dan 8.

Tabel 5. Profil terapi kombinasi obat antihipertensi pada pasien gagal ginjal kronik yang menjalani hemodialisa

\begin{tabular}{|c|c|c|c|c|c|c|}
\hline $\begin{array}{l}\text { Nama Golongan } \\
\text { Kombinasi Obat } \\
\text { Antihipertensi }\end{array}$ & $\begin{array}{l}\text { Jumlah } \\
\text { Pasien }\end{array}$ & $\begin{array}{l}\text { Persentase } \\
\text { (\%) }\end{array}$ & Nama Generik Obat & & Jumlah & $\begin{array}{l}\text { Persentase } \\
\text { (\%) }\end{array}$ \\
\hline \multirow[t]{5}{*}{$1 \mathrm{ARB}+1 \mathrm{CCB}$} & 18 & 95 & Irbersartan $300 \quad \mathrm{mg}$ & + & 12 & 63 \\
\hline & & & Amlodipin 10 mg & & & \\
\hline & & & Irbersartan 150 & + & 5 & 37 \\
\hline & & & Amlodipin $10 \mathrm{mg}$ & & & \\
\hline & & & $\begin{array}{l}\text { Irbersartan } 150 \quad \mathrm{mg} \\
\text { Amlodipin } 5 \mathrm{mg}\end{array}$ & + & 1 & 5 \\
\hline \multirow[t]{2}{*}{$1 \mathrm{ARB}+2 \mathrm{CCB}$} & 1 & 5 & Irbersartan $150 \mathrm{mg}$ & + & 1 & 5 \\
\hline & & & $\begin{array}{l}\text { Amlodipin } 10 \mathrm{mg}+\text { Adala } \\
\text { Oros } 30 \mathrm{mg}\end{array}$ & & & \\
\hline Total Pasien & 19 & 100 & & & 19 & 100 \\
\hline
\end{tabular}

Tabel 6. Profil dosis dan frekuensi pemberian dari terapi kombinasi obat antihipertensi pada pasien gagal ginjal kronik yang menjalani hemodialisa

\begin{tabular}{lcccc}
\hline $\begin{array}{l}\text { Nama Generik } \\
\text { Obat }\end{array}$ & Dosis & Aturan Pakai & Jumlah & Persentase (\%) \\
\hline Irbersartan & $300 \mathrm{mg}$ & $1-0-0$ & 12 & 63 \\
& $150 \mathrm{mg}$ & $1-0-0$ & 7 & 37 \\
Amlodipin & $10 \mathrm{mg}$ & $0-0-1$ & 18 & 95 \\
& $5 \mathrm{mg}$ & $0-0-1$ & 1 & 5 \\
Nifedipin Oros & $30 \mathrm{mg}$ & $0-1-0$ & 1 & 5 \\
\hline
\end{tabular}

Tabel 7. Profil terapi obat oral antidiabetes dan insulin pada pasien gagal ginjal kronik yang menjalani hemodialisa

\begin{tabular}{|c|c|c|c|c|}
\hline $\begin{array}{l}\text { Kategori } \\
\text { Obat }\end{array}$ & $\begin{array}{c}\text { Nama Generik OAD } \\
\text { dan Dosis }\end{array}$ & $\begin{array}{c}\text { Frekuensi } \\
\text { Pemberian OAD }\end{array}$ & $\begin{array}{l}\text { Jumlah } \\
\text { Pasien }\end{array}$ & Persentase (\%) \\
\hline Insulin & & & 10 & 67 \\
\hline OAD & Glikuidon 30 mg & $1-0-0 \mathrm{ac}$ & 3 & 20 \\
\hline $\begin{array}{l}\mathrm{OAD} \\
\text { Insulin }\end{array}+$ & Glikuidon $30 \mathrm{mg}$ & $1-0-0 \mathrm{ac}$ & 2 & 13 \\
\hline Total & & & 15 & 100 \\
\hline
\end{tabular}


Tabel 8. Profil penggunaan kombinasi insulin, kombinasi insulin dengan $O A D$, insulin tunggal, OAD tunggal beserta dosis dan frekuensi pemberian pada pasien gagal ginjal kronik yang menjalani hemodialisa

\begin{tabular}{|c|c|c|c|c|}
\hline Golongan Obat & Dosis & $\begin{array}{l}\text { Frekuensi } \\
\text { Pemberian }\end{array}$ & $\begin{array}{l}\text { Jumlah } \\
\text { Pasien }\end{array}$ & $\begin{array}{l}\text { Persentase } \\
\text { (\%) }\end{array}$ \\
\hline \multicolumn{5}{|l|}{ Golongan Kombinasi Insulin atau } \\
\hline \multicolumn{5}{|l|}{ Golongan Kombinasi Insulin + OAD } \\
\hline $\begin{array}{l}\text { Insulin Analog Kerja Panjang + } \\
\text { Insulin Aspart Analog Kerja Cepat }\end{array}$ & $6 \mathrm{UI}+10 \mathrm{UI}$ & $\begin{array}{c}0-0-6 \text { UI sc } \\
3 \text { dd } 10 \text { UI sc }\end{array}$ & 3 & 34 \\
\hline & $6 \mathrm{UI}+20 \mathrm{UI}$ & $\begin{array}{c}0-0-6 \text { UI sc } \\
3 \text { dd } 20 \text { UI sc }\end{array}$ & 2 & \\
\hline $\begin{array}{l}\text { Insulin Analog Campuran: aspart } \\
30 \%+\text { aspart protamin } 70 \%\end{array}$ & $10 \mathrm{UI}$ & $3 \mathrm{dd} 10 \mathrm{UI} \mathrm{sc}$ & 2 & 13 \\
\hline $\begin{array}{l}\text { Insulin Analog Kerja Panjang + } \\
\text { Insulin Analog Campuran: aspart } \\
30 \%+\text { aspart protamin } 70 \%\end{array}$ & $6 \mathrm{UI}+10 \mathrm{UI}$ & $\begin{array}{l}0-0-6 \text { UI sc } \\
3 \text { dd } 10 \text { UI sc }\end{array}$ & 1 & 6,6 \\
\hline $\begin{array}{l}\text { Sulfonilurea + Insulin Analog } \\
\text { Kerja Panjang + Insulin Aspart } \\
\text { Analog Kerja Cepat }\end{array}$ & $30 \mathrm{mg}+6 \mathrm{UI}+6 \mathrm{UI}$ & $\begin{array}{c}1-0-0 \text { ac } \\
0-0-6 \text { UI sc } \\
3 \text { dd } 6 \text { UI sc }\end{array}$ & 1 & 6,6 \\
\hline $\begin{array}{l}\text { Sulfonilurea + Insulin Analog } \\
\text { Campuran }\end{array}$ & $30 \mathrm{mg}+6 \mathrm{UI}+10 \mathrm{UI}$ & $\begin{array}{c}1-0-0 \text { ac } \\
0-0-6 \text { UI sc } \\
3 \text { dd } 6 \text { UI sc }\end{array}$ & 1 & 6,6 \\
\hline \multicolumn{5}{|l|}{ Golongan Insulin tunggal } \\
\hline Insulin Aspart Analog Kerja Cepat & $6 \mathrm{UI}$ & $3 \mathrm{dd} 6 \mathrm{UI} \mathrm{sc}$ & 1 & 6,6 \\
\hline Insulin Analog Kerja Panjang & $6 \mathrm{UI}$ & $0-0-6$ UI sc & 1 & 6,6 \\
\hline \multicolumn{5}{|l|}{ Golongan OAD tunggal } \\
\hline Sulfonilurea & $30 \mathrm{mg}$ & $1-0-0$ ac & 3 & 20 \\
\hline Total & & & 15 & 100 \\
\hline
\end{tabular}

Penggunaan OAD golongan sulfonilurea pada pasien DM komplikasi PGK dengan hemodialisa berdasarkan hasil penelitian ini dikarenakan golongan sulfonilurea mempunyai kontrol gula darah yang baik, sehingga dapat menghambat progresifitas penurunan fungsi ginjal dengan pengamatan pada parameter penurunan albuminuria. (Perkeni, 2015). Mekanisme kerjanya yaitu stimulasi insulin pada kelenjar $\beta$ pankreas. Glikuidon merupakan sulfonilurea generasi kedua yang mempunyai keuntungan yaitu efek hipoglikemianya rendah. Keuntungan lain penggunaan glikuidon pada pasien DM dengan PGK adalah glikuidon di ekskresi melalui sistem billier sehingga tidak mempengaruhi fungsi ginjal dalam proses ekskresi obat dalam tubuh jadi tidak perlu dilakukan penyesuaian dosis pada pasien DM dengan PGK ini. Tetapi belum ditemukan penelitian lebih lanjut tentang efikasi glikuidon pada pasien PGK.

Berdasarkan Perkeni (2015) tujuan penggunaan insulin pada penelitian ini adalah untuk mengontrol kadar gula darah dari pasien DM dengan PGK yang menjalani HD, selain itu juga pemberian injeksi insulin sangat aman bagi pasien PGK. Pada pemakaian kombinasi insulin yang terbanyak digunakan pada penelitian ini adalah 
insulin kerja panjang + insulin aspart analog kerja cepat. Pemberian insulin kerja panjang bertujuan untuk mencapai sasaran glukosa darah basal. Jika glukosa darah basal telah tercapai maka selanjutnya dilakukan pengendalian glukosa darah prandial dengan pemberian insulin kerja cepat yang disuntikkan 5-10 menit sebelum makan, atau jika diberikan insulin kerja pendek diberikan 30 menit sebelum makan (Perkeni, 2015). Pada penelitian ini terapi insulin tunggal ataupun kombinasi disesuaikan dengan kondisi klinik pasien dan berdasarkan pada pemeriksaan glukosa darah harian. Sedangkan pemberian kombinasi antara $O A D$ golongan sulfonilurea dengan insulin kerja panjang atau kerja campuran pada penelitian ini bertujuan agar setelah tercapai glukosa basal dengan pemberian insulin, maka untuk menurunkan glukosa prandial diberikan $O A D$ golongan sulfonilurea yang pada penelitian ini diberikan glikuidon 1 kali sehari 1 tablet sebelum makan (Perkeni, 2015).

\section{Simpulan}

Berdasarkan hasil penelitian dan pembahasan, maka dapat disimpulkan bahwa penggunaan obat antianemia terbanyak pada pasien anemia dengan PGK yang menjalani HD adalah epo alfa (a) dosis $2000 \mathrm{UI}$ sebanyak $60 \%$ pasien dan dapat meningkatkan $\mathrm{Hb}$ pasien. Untuk obat antihipertensi terbanyak yang digunakan pada pasien hipertensi dengan PGK yang menjalani HD adalah golongan $A R B$ yang dikombinasi dengan golongan CCB dengan nama generik irbersartan $300 \mathrm{mg}$ dan amlodipin $10 \mathrm{mg}$ dan frekuensi pemberiannya 1 kali sehari 1 tablet sebanyak 63\% pasien. Sedangkan untuk pasien diabetes dengan PGK yang menjalani HD, penggunaan $O A D$ tunggal terbanyak adalah golongan sulfonilurea dengan nama generik glikuidon dosis $30 \mathrm{mg}$ dengan frekuensi pemberian 1 kali sehari 1 tablet diminum 15-30 menit sebelum makan pagi sebanyak $20 \%$ pasien. Untuk penggunaan insulin, kombinasi insulin pemakaian terbanyak adalah insulin analog kerja panjang kombinasi insulin analog kerja cepat sebanyak $34 \%$ pasien. Sedangkan penggunaan kombinasi OAD golongan sulfonilurea dengan insulin sebanyak $13 \%$ pasien

\section{Daftar Pustaka}

Ahmad, R., Habib, A., Rahman, S. 2016. Management of hypertension in patients with end-stage renal disease leading to haemodialysis: a challenge. International Journal of Advances in Medicine, 3(4):790798.

Burns, A., Ashley, C., Currie, A. (Eds). 2009. The Renal Drug Handbook. Third Edition. New York: Redicliffe Publishing Ltd.

Hooffbrand, A.V., Pettit, J.E., Moss, P.A.H. 2012. Hematologi. Jakarta: EGC.

Lankhorst, C.E. dan Wish, J.B. 2010. Anemia in renal disease: diagnosis and management. Blood Review, 24(1):39-47. 
Lewis, E.J., Hunsicker, L.G., Clarke, W.R. 2001. Renoprotective effect of the angiotensin-receptor antagonist irbesartan in patients with nephropathy due to type 2 diabetes. The New England Journal of Medicine, 345(12):851-860.

NKF. 2002. Clinical practice guidelines for chronic kidney disease in K/DOQI: Evaluation, Classification and Stratification. New York: National Kidney Foundation Inc.

Paranoan, R., Manggau, M.A., Kasim, H., Djide, M.N., Lallo, S., Djabir, Y.Y. 2019. Analisis efektivitas dan efek samping penggunaan antihipertensi pada pasien gagal ginjal kronik rawat inap di RSUP
Dr. Wahidin Sudirohusodo. Majalah Farmasi dan Farmakologi, 23(1):13-15.

Perkeni. 2015. Konsensus Pengelolaan dan Pencegahan Diabetes Mellitus Tipe 2 di Indonesia. Cetakan Pertama. Jakarta: PB Perkeni.

Pranandari, R. dan Supadmi, W. 2015. Faktor resiko gagal ginjal kronik di unit hemodialisis RSUD Wates Kulon Progo. Majalah Farmaseutik, 11(2):316-320.

Suprapti, B. dan Nilamsari, W.P. 2013. Farmakoterapi Diabetes Mellitus: modul CPD. Surabaya: Pusat Penerbitan dan Percetakan Unair (AUP). 